\title{
МЕДІАДОСЛІДЖЕННЯ
}

\author{
Visn. Lviv. Univ., Ser. Zhurn. 2019: 46; 364-370 • DOI: http://dx.doi.org/10.30970/vjo.2019.46.10075
}

УДК 070.431.5(045)

\section{ОБРАЗ УКРАЇНИ У ЗМІ ФРАНЦІї}

\author{
Софія Ворончук \\ Львівський національний університет імені Івана Франка, \\ вул. Генерала Чупринки, 49, Львів, 79044, Україна, \\ e-mail: sofiavorontchouk17@gmail.com \\ https://orcid.org/0000-0001-7204-8431
}

У статті досліджено формування іміджу України засобами масової інформації Франції. Визначено чинники, що впливають на тональність публікацій, та труднощі у створенні позитивного образу України. Проаналізовано праці, які стосуються образу України у мас-медіа Франції.

Ключові слова: образ України, міжнародний імідж, інформаційний простір, Франція, ЗМІ.

Вступ. Від політичної модернізаціїі держави та суміжних процесів залежить ступінь демократичності інформаційно-комунікативних потоків, а також формування і розвиток позитивного іміджу. Це є важливою умовою соціальної стабільності всередині країни та успішного міжнародного співробітництва за їі межами [9]. Позитивний образ держави та їі громадян у масовій суспільній свідомості потрібний передусім для успішного просування та реалізації національних інтересів.

Об’єктом статті обрано французькі мас-медіа не випадково. Франція, як одна 3 найвпливовіших країн Свропи, учасниця Нормандської четвірки та одна із сторін Мінських угод, є постійним партнером України в міжнародних відносинах. Вона $\epsilon$ свідком політичних змін в Україні. Тож підтримка та лобіювання важливих для нашої держави питань-відповідей залежить й від іміджу України як серед політичної верхівки, так і звичайних французів. Для більшості європейських громадян особисте знайомство з Україною є неможливим, тому саме преса, радіо й телебачення формують уявлення про нашу країну.

Постановка проблеми. Сьогодні перед Україною стоїть завдання створення ефективного бренду й формування позитивного образу на міжнародній арені. Сучасний український інформаційно-культурний простір за його нинішньої структури та наповненості не адаптований до вирішення такого суспільно значущого завдання. Аби утвердити позитивний образ й розвінчати негативні стереотипи, потрібно

(C) Ворончук С., 2019

Наукове керівництво, редагування і рекомендація - к. філол. н., Михайличенко Н. С. 
проаналізувати, що саме знають, чують, читають та бачать французи про суспільне й політичне життя українців. Основним завданням є створення сучасного образу України у світі, що є важливим складником і національної безпеки. Роль ЗМІ в цьому контексті досліджена недостатньо і побіжно. Тому наше завдання - чітко окреслити шлях до формування позитивного образу Української держави у свідомості світу крізь призму французьких 3МI.

Аналіз останніх досліджень та публікацій. Над дослідженням цієї теми працювали як українські науковці (Б. Цимбалістий, О. Семченко, Я. С. Калакура, О. О. Рафальський, М. Ф. Юрій, О. Петкова, О. Зубик), так і зарубіжні (Філіпп де Лара, О. Ігнатова, А. Реан). Зокрема, ментальний вимір української цивілізації вивчали Я.С.Калакура, О. О. Рафальський, М. Ф. Юрій [3]. Найновіші дослідження впливу ЗМІ на свідомість слухачів і глядачів у контексті інформаційної безпеки й незалежності держави зібрані й систематизовані у книзі професора В. Лизанчука «Інформаційна безпека України: теорія і практика» [4]. На базі досліджень О. Зубик «Імідж України з-за меж» та Ю. Кирилова «Бренд України в глобалізованому світі: визначення перспективних образів» деякі спеціалісти політико-інформаційного менеджменту вивчали також висвітлення подій в Україні французькими ЗМI, проте тема сьогодні майже не досліджена [12].

Мета статті - проаналізувати праці науковців, що порушували тему висвітлення подій в Україні французькими мас-медіа; систематизувати чинники, що вплинули на формування образу України засобами масової інформації у Франції.

Виклад основного матеріалу. Ментальне обличчя української цивілізації формувалося історично - про це говорять такі дослідники, як Ярослав Калакура, Олег Рафальський та Михайло Юрій. Від Княжої доби, коли давньоукраїнська держава творила владно-політичний менталітет під впливом християнства й основ етнічної самосвідомості, до Галицько-Волинського князівства, де ці риси утверджувалися. У козацько-гетьманські часи українці започаткували глибинні зв'язки й усвідомили себе наступниками Києворуської держави. Доба Австро-Угорської та Російської імперій сформували, з одного боку сприйняття України як «Малоросії», а з іншого, створила образ нації, що прагне свободи. Саме тому поряд із демократичністю, толерантністю і лагідністю українському народові притаманна певна відчуженість, інтровертивність та анархізм [3].

Про ці історичні особливості ментальності треба знати, та їх не варто перебільшувати, адже однією з найважливіших функцій держави є зміцнення ідей, що стоять на сторожі національного ядра народу, ідей, які формують імідж держави у світі. Безпосередній обов'язок уряду перед своїми громадянами - сприяти утвердженню національної ідентичності та оберігати цілісність держави. У цій сфері уряд спирається на діяльність 3МІ, що всією своєю сутністю відповідають визначеній меті. Саме тому мас-медіа й найбільше впливають на формування бренду й іміджу держави як на внутрішньому, так і на зовнішньому рівні. Адже вони постійно взаємодіють із чинниками, що творять образ країни.

Імідж держави формується за допомогою низки чинників, а саме: природний потенціал; національна і культурна спадщина; геополітичні фактори; історичні фактори; форма державного устрою і структура управління; соціально-психологічний стан суспільства; форми суспільно-політичної інтеграції; морально-етичні аспекти розвитку суспільства; стійкість економіки; правовий простір; функції, повноважен- 
ня і механізми державного регулювання різних сфер суспільного життя; ефективність владної конструкції [5, с. 13].

На міжнародній медіаарені на зміну тривалому ігноруванню українського фактора західними 3МІ прийшло зосереджене спостереження за цим уламком пострадянського простору, де розгорталася політична криза, яка набрала форми силового зіткнення між альтернативними баченнями сьогодення та майбутнього [13]. Робота дипломатів над іміджем України залишатиметься неуспішною доти, доки позитивне сприйняття держави буде залишатися здобутком лише окремих верств політичної, бізнесової та журналістської еліти, яка співпрацює з владою, а не буде опиратися на консенсусне бачення, виражене в оцінках експертів і в настроях суспільної думки. Інакше кажучи, позитивний імідж держави не може стати фактом внутрішньої самооцінки суспільства. Утвердження негативного сприйняття держави в міжнародних інформаційних потоках, агресивний культурний колоніалізм, зросійщення, глобалізація і хаотичний мультикультуралізм мають небезпеку нівелювання власної ідентичності, вважає професор В. Лизанчук [4]. I, звичайно, загрожує її цілісності та незалежності, в чому нас переконали події 2014-2018 років.

Саме тому існує нагальна потреба аналізу українських та закордонних вчених на тему висвітлення подій, що відбуваються в Україні, і їхній вплив на формування образу нашої держави. На жаль, досліджень не так і багато, хоча нас поєднує із Францією постійне партнерство ще з часів Анни Ярославни і до Мінських угод. Дослідник О. Бутирський зазначає, що зображення України в західних 3МІ зі здобуттям незалежності можна поділити на кілька періодів: політична криза, Україна як плацдарм боротьби за сфери впливу між двома гігантами - Росією та США, зближення України та Росії, зміна українського уряду, візит папи Римського в Україну, Україна ювілейна: 10 років незалежності, Україна кримінальна: справа Солтиса [1]. Тобто образ українця 10 років після здобуття офіційної самостійності був східноцентричний. Там нас сприймали як уламок радянщини. I сприяло цьому телебачення й радіомовлення, до того ж сусідське.

Інформаційну присутність України у двох найпопулярніших французьких газетах «Le Figaro» та «Le monde» за період 2004-2009 років розглянули I. Стукан, I. Coпіга у статті « Імідж України у французьких і німецьких друкованих засобах масової інформації» [6]. У більшості публікацій, як зазначають дослідники, Україна згадується лише побіжно, у матеріалах, основною темою яких є повідомлення про події у світі або про події в конкретній країні. Хоча навіть суміжне повідомлення створює інформаційний привід, що допомагає популяризації країни. Тому в разі негативних повідомлень автоматично спотворюється й український «образ». Публікації з «українськими питаннями» в ЗМІ Франції неоднорідні: після певної паузи і відсутності повідомлень щодо України, згодом з'являється значна кількість статей. Впливають на це, звичайно, суспільно-політичні зміни в нашій державі, а також у міжнародних відносинах [6]. Помаранчева революція 2004 р. на деякий час змінила на краще ставлення світу до українців. Ця революція розвінчала багато міфів і стереотипів про Україну. Змінилися політичні стереотипи: «кучміз», «радянськість», «злочинність» на «помаранчева Україна», «помаранчева опозиція», «цінності майдану»; економічні: «Україна - Росія №2», «підніжка Москви», «ворог ЄС» на «європейська держава», «партнер ЄС» [11]. Найбільшу увагу приділяють політичному життю держави, а також міжнародним відносинам України. Спортивні події та культурно-науковий 
розвиток висвітлюють лише в період великих спортивних змагань або під час масштабних культурних подій чи візитів [11] .

Ще одним доказом, що у французьких ЗМІ Україну згадують лише побіжно, $\epsilon$ інформаційно-бібліографічний бюлетень «Фонду Президентів України» «Україна у відгуках зарубіжної преси». У цьому бюлетені подано оперативну інформацію про Україну, опубліковану на сторінках зарубіжних ЗМІ. Щомісяця, починаючи із січня 2012 р., тут висвітлюють події та подають аналіз процесів, що відбуваються в Україні, зокрема діяльність органів законодавчої, виконавчої та судової влади, місцевого самоврядування, актуальні питання міжнародного співробітництва та суспільно-політичного життя. Публікації зібрані з електронних ресурсів 77 зарубіжних періодичних видань країн Європи, Азії та Америки [8].

Показово, що у першому січневому випуску бюлетеня 2012 року про Україну у Франції згадали лише два рази, у рубриках «Політична боротьба» та «Інформація». Газета «Le Figaro» та паризька «France Soir» написали про нашу державу в контексті згадки про доньку Юлії Тимошенко та її запрошення в Сенат США, що $\epsilon$ позитивом для образу України і через отруєння сина президента Франції Ніколя Саркозі в Одесі. Стаття додала негативу уявленню про Україну [15]. Натомість уже в 2014-му ситуація починає змінюватися, представники західних ЗМІ активно працюють в Україні і подають досить зважену інформацію, проте є певні проблеми, на які варто звернути увагу. Про це зазначає медіаексперт Володимир Єрмоленко, представник «Інтерньюз-Україна», викладач Києво-Могилянської Академії, пише «Media Sapiens». За його словами, однією з проблем є особливий акцент на українських ультраправих рухах, про які згадують чи не всі закордонні медіа. Хоча подібні статті врівноважуються матеріалами інших видань, котрі «мають суттєво відмінну тональність і називають речі своїми іменами». Те саме можна сказати і про французькі ЗМІ, які навіть «симпатизують нашій революції» [6].

Після Революції Гідності Україну перестали сприймати як країну в затінку Роciï. Вона нарешті почала по-справжньому «існувати» в головах європейців, а вони неочікувано для себе «відкрили» їі. Філіпп де Лара - філософ, професор Університету Париж II, керівник програми «Сучасність і тоталітаризм». Співпрацює з виданням «Український тиждень» [11]. Він зазначає, що до 2014 року для французів України не існувало. Ставлення французів (і не лише французів) до України відповідає феномену «стрічки Мебіуса», коли можна спокійно переходити з одного боку на інший, від екзальтації до упередження і навпаки. Окрім того, є багато міфів, які підсилює російська маніпулятивна пропаганда. 3 одного боку, для французів Україна - це європейська нація, і зміни, які відбуваються, відповідають духові Європи, але, з іншого боку, події в Україні відповідають найгіршим зразкам націоналістичних рухів. Путін - імперіаліст, диктатор, а українці для деяких французів - це лише різновид росіян. За словами професора, СС та його члени перебувають зараз в глибокій кризі - кризі ідентичності. Науковець виокремив три хвороби, які стосуються кризи Європи. Перша - це забуття і нерозуміння феномену кордонів. Друга - європейці перестали розуміти сенс нації. Третя хвороба - це забуття комунізму. Україні доводиться постійно маневрувати для того, щоб не дозволити надягти на неї чужий піджак - «піджак російського імперіалізму» насамперед. Протягом останніх двох років українські військові та волонтери відіграли найважливішу роль у формуванні 
іміджу України, оскільки зуміли відстояти суверенітет України та продемонструвати, що вона існує [11].

Проте є й зовсім протилежні погляди у французьких дослідженнях. До прикладу після перегляду достатньо поважного французького сайту «Центр досліджень глобалізації» ми зрозуміли, що практично всі статті одного із авторів висвітлюють відносини України та світу із погляду «проросійського». Постійний автор ще з 2014 року П'єр Ван Гандерберк , який отримує найбільше переглядів і вважається експертом в «українському питанні», очевидно, має особливо негативний погляд. Візьмімо до перегляду матеріал «Україна та глобальні медіа: західна пропаганда проти Путіна», де дослідник аналізує, чому ж західні, і зокрема французькі медіа, працюють проти Росії. Називає дві причини: протистояння поміж США та Росією і нацистські погляди України. Себто французи постійно читають про те, що єдиним виходом із кризи XXI сторіччя, із можливої небезпеки з боку Росії є федералізація України та їі недопуск в НАТО та ЄС [9]. Проте це добре спланована маніпуляція, яка не має ніякої протидії із боку України та її медіа. Образ нашої держави постає для французів дуже неоднозначним: неонацисти ми, чи жертви, чи європейці, або ж націоналісти?! Та ми надто далеко інформаційно, щоб подолати цей бар'єр швидко.

Французька «Обсерваторія журналістики», яка «пише про тих, хто пише», себто про мас-медіа у Франції, на жаль, засуджує лояльність французьких ЗМІ до України. Такий погляд має також автор статті «Французькі ЗМІ в українській кампанії» Матіас Реймонд. Автор статті вважає, що французькі медіа дуже швидко обрали українську сторону в конфлікті Україна - Росія, і це виглядає навіть гротескно, зважаючи на помпезні слова політиків та заголовки матеріалів журналістів. «Путін - не Гітлер, але...», - каже М. Реймонд, але ЗМІ у Франції зробили його таким [10].

Незважаючи на це, про Україну у Франції говорять тепер частіше й більше. Про це свідчить останній випуск Інформаційно-бібліографічного бюлетеня 2019 року, де за два тижні нового року про нас згадали аж тричі. I це вже матеріали про Україну, а саме про іï суспільно-політичну ситуацію. Перший матеріал стосується виборів 2019 року й, вважаємо, є глибоким, адже аналізує не лише кандидатів у Президенти, а й другі політичні ролі. Наступна згадка - це порівняння протистоянь у Франції та Майдану в Україні, а останній матеріал розповідає про Різдво та Томос [14].

Інформація - носій демократичних, культурологічних засад, тому події життя українців мусять з'являтися частіше на екранах телевізорів, у радіоефірі, показувати ix треба сміливо та цікаво, бо тільки так можна відшукати аналітично мислячих людей, спеціалістів у галузі стратегії бізнесу, економіки, політики, державності, а їх залучення може принести економічний успіх, і тоді не треба буде шукати «трагічних оптимістів, жертовних патріотів і розв'яжеться проблема плинності кадрів. Україна має великий економічний та інтелектуальний потенціал, який нині використовують недбало, а почасти й злочинно. І завдання засобів масової інформації в тому, щоб задіяти цей потенціал, сформувати нормальні суспільні відносини, інтегруватися в міжнародні структури як цивілізована держава [8].

Висновки. У час гібридної війни Росії проти України інформація відіграє і стратегічну роль. Тому журналісти повинні зайняти українськоцентричну позицію й своєю працею формувати образ України як серед їі жителів, так і серед іноземних реципієнтів. Наше коротке дослідження свідчить, що незважаючи на те, що сьогодні 21 століття і отримати інформацію можна багатьма способами, люди все ж під- 
даються звичайній маніпуляції, бо їм важко, «затратно» перевірити те, що почули, побачили чи прочитали. Тож образ й імідж України формують повідомлення, які іноземні держави отримують у звичному режимі: через побіжні матеріали новин, згадки у статтях, розповідях у блогах та із досліджень неукраїнських вчених! Саме тому ми повинні об’єднати всі наші сили, щоб протистояти як ворогові, так і незнанню та байдужості.

По-перше, потрібно створити інституцію, яка б об'єднувала або координувала всі, які вже існують: Нацраду з телебачення та радіомовлення, РНБО України, Міністерство інформаційної політики, до якої б надходила ця інформація, яка би розробляла такі меседжі, робила моніторинг та аналіз. Це може бути МЗС, Інститут іміджу (як у багатьох країнах Скандинавії), інформаційна служба Президента.

По-друге, пропрацювати іміджеву програму, за допомогою якої можна залучати до країни туристів, інвесторів та мігрантів, але підходи як до цих груп, так і до різних країн мають бути різними. Потрібно робити цільові програми на цільову аудиторію.

По-третє, потрібно виходити на міжнародну арену, створивши потужний медіаканал, який би говорив як українською, так і іноземними мовами, давав погляд зсередини. I, звичайно, нам потрібно почати співпрацювати з іноземними телерадіоорганізаціями й журналістами, започаткувавши єдиний канал інформаційних повідомлень, щоб їх було цікаво використовувати у випусках новин. I щоб наші сусіди нарешті перестали говорити замість нас!

\section{REFERENCES}

1. Бутирський О. А. Україна у дзеркалі західних 3МІ / А. О. Бутирський // Вісник Київського національного ун-ту імені Тараса Шевченка. Сер. Журналістика. 2003. Вип. 11. С. 53-54.

2. Гребініченко О. Ю. Міжнародні рейтинги України як фактор впливу на національну безпеку держави: дис. на здобуття ступеня кандидата політ. наук : 21.01.01 / Гребініченко Олександр Юрійович. К., 2008. 221 с.

3. Калакура Я.С., Рафальський О.О., Юрій М.Ю. Ментальний вимір української цивілізації / Я.С. Калакура, О.О. Рафальський, М.Ю. Юрій - Київ: Генеза, 2017. 560 с.

4. Лизанчук В. В. Інформаційна безпека України: теорія і практика: підручник / Василь Васильович Лизанчук. Львів: ЛНУ ім. Івана Франка, 2017. 728 с.

5. Петкова О. Методичні аспекти дослідження іміджу країни / О. Петкова // Політичний менеджмент. № 5. 2008. С. 168-174.

\section{Інтернет-ресурси}

6. https://ms.detector.media/ethics/standards/frantsuzki zmi simpatizuyut ukrainskiy revolyutsii_a nimetski bilsh vivazheno pishut pro ukrainu volodimir_ermolenko/

7. https://naub.oa.edu.ua/2010/imidzh-ukrajiny-u-frantsuzkyh-i-nimetskyh-drukovanyhzasobah-masovoji-informatsiji/

8. https://www.libr.dp.ua/PDP/ua1.PDF

9. https://www.mondialisation.ca/ukraine-et-medias-dominants-propagande-occidentalecontre-poutine/5399726 
10. https://www.ojim.fr/les-medias-francais-et-lukraine/

11. https://www.prostir.ua/?focus=obraz-ukrajiny-za-kordonom-yak-strichka-mebiusa

12. http://www.experts.in.ua/analytics/document7779.shtml

13. http://journlib.univ.kiev.ua/index.php?act=article \&article $=1878$

14. http://nbuviap.gov.ua/images/ukraina_y_vigykax/2019/1.pdf

15. http://nbuviap.gov.ua/images/ukraina_y_vigykax/2012/1.pdf

\title{
THE IMAGE OF UKRAINE IN THE FRENCH MEDIA
}

\author{
Sofiia Voronchuk \\ Ivan Franko National University of Lviv, \\ Generala Chuprynky Str., 49, 79044, Lviv, Ukraine \\ e-mail: sofiavorontchouk17@gmail.com \\ https://orcid.org/0000-0001-7204-8431
}

The article deals with the problems of forming the image of Ukraine by the world mass media, on the example of France's mass media. The factors influencing the tonality of publications, and the difficulties in creating the external image of Ukraine in the French media are determined. The article is aimed at the study of theoretical studies on the image of Ukraine in the mass media of France. The paper also examines literature that reveals the mental image of Ukrainian civilization, and presents a study on this topic. It also indicates the influence of positive and negative features of the socio-political situation in Ukraine on the international image and the formation of a national image. In particular, the issue of the image of the state, which is shaped by the media and their role in this process, is considered in the paper. Attention is paid to the features of the information component of the image of the state. The attention is paid to the basic methods and means of forming an image, as well as the influence of information technologies and mass media on the creation of this or that image of the state. The features of media relations and political image of the state are revealed. The communication of the socio-political situation and information that exists in the information-only France, which serves as a partner in many important issues for Ukraine, is systematized. The article also examines the growing role of the media in shaping the country's internal and external course. The article comprehensively examines the features of the coverage of Ukrainian events in the French media, the factors of their formation and methods of influencing the public opinion of the external information space. The values of the Ukrainian factoring for interethnic processes through the materials of mass media in France and its use for creation of the foreign policy image are determined.

Key words: image of Ukraine, international image, information space, France, media. 